Неоніла КУЦЕНОК,
огсіd.оrg/0000-0001-7111-0088
викладач кафедри англійської мови технічного спрямування № 2
Наиіонального технічного університету Украӥни
«Київський політехнічний інститут імені Ігоря Сікорського»
(Київ, Украйна) nila15@ukr.net

Наталія ЯМШИНСЬКА, orcid.org/0000-0002-0518-3657

викладач кафедри англійської мови технічного спрямування № 2

Національного технічного університету України «Київський політехнічний інститут імені Ігоря Сікорського» (Київ, Украӥна)nyamshinska@ukr.net

Ірина СТАВИЦЬКА, orcid.org/0000-0003-4915-0141 кандидат педагогічних наук, доиент кафедри англійської мови технічного спрямування № 2 Національного технічного університету України «Київський політехнічний інститут імені Ігоря Сікорського» (Київ, Україна) iryna_stavytska@ukr.net

\title{
АНАЛІЗ ПІДГОТОВКИ БАКАЛАВРІВ ДО ЗДАЧІ СВІ З ІНОЗЕМНОЇ МОВИ У ЗАКЛАДАХ ВИЩОЇ ОСВІТИ В УМОВАХ ОЧНОГО ТА ДИСТАНЦІЙНОГО РЕЖИМУ НАВЧАННЯ
}

\begin{abstract}
Автори статті акцентують увагу на особливостях підготовки бакалаврів до здачі ЄВI з іноземної мови у закладах вищої освіти в умовах очного та дистаниійного режиму навчання, розкривають переваги та недоліки підготовки студентів бакалаврату до вступу у магістратуру та отримання наступного ступеня вищої освіти диплома магістра.

Проводиться аналіз апробованих платформ, які були застосовані минулого навчального року $і$ довели результативність під час здачі СВI безпосередньо у Національному технічному університеті Украӥни «Київському політехнічному інституті імені Ігоря Сікорського».

Стаття містить огляд підручників, які були використані викладачами окремого університету для підготовки студентів для складання єдиного вступного іспиту, наводяться приклади апробації навчальної літератури, націленої на практикування необхідних для успішного складання іспиту мовленнєвих умінь та навичок.

Проводиться порівняльна характеристика типових вправ, які були рекомендовані до підготовки до складання єдиного вступного іспиту з англійської мови для вивчення лексичних одиниць, граматичних структур, які б дали можливість майбутнім абітурієнтам проявити сформовані вміння читати текст та розуміти зміст прочитаного, вільно орієнтуватися у завданнях, спрямованих на перевірку здатності відтворити повну або часткову інформацію чи знайти певні факти з прочитаного.

3 метою підтвердження ефективності та необхідності здійснення системної та иілеспрямованої роботи з комплексної підготовки для складання іспиту, авторами був проведений моніторинг показників успішності виконання типових для іспиту вправ студентами 4 курсу бакалаврату. У статті надаються результати проведеного оцінювання успішності виконання студентами завдань, представлена статистика середніх показників правильних відповідей. На основі отриманих результатів зроблено висновки щчодо дочільності й ефективності використання рекомендованих посібників під час підготовки студентів до здачі єдиного вступного іспиту з іноземної мови та надані рекомендачії щзоо формату вправ, які можна пропонувати студентам для виконання під час занять в аудиторії, а також дистаниійної форми навчання.

Попри певні складнощі переходу від аудиторних занять до дистанційного режиму очного навчання, практиками, методистами та фахівцями-науковиями постійно робляться пошуки нових методів реалізації освітніх завдань, демонструються певні методичні наробки, які здатні успішно реалізувати підготовку майбутніх фахівців за умов як очного, так і дистанційного навчання.
\end{abstract}

Ключові слова: СВI (єдиний вступний іспит), стратегї̈ складання іспиту, дистаниійний режим очного навчання, типові вправи, лексичний мінімум, граматичні структури. 
Куценок Н., Ямшинська Н., Ставицька I. Аналіз пілготовки бакамаврів мо здачі СBI ...

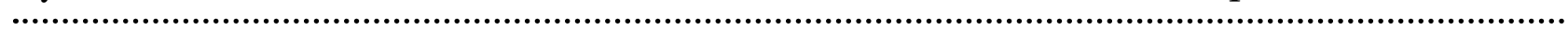

Neonila KUTSENOK,

orcid.org/0000-0001-7111-0088

Lecturer at the Department of Technical English № 2

National Technical University of Ukraine "Igor Sikorsky Kyiv Polytechnic Institute"

(Kyiv, Ukraine)nila15@ukr.net

Nataliia YAMSHYNSKA,

orcid.org/0000-0002-0518-3657

Lecturer at the Department of Technical English № 2

National Technical University of Ukraine "Igor Sikorsky Kyiv Polytechnic Institute"

(Kyiv, Ukraine)nyamshinska@ukr.net

Iryna STAVYTSKA, orcid.org/0000-0003-4915-0141

Candidate of Pedagogical Sciences,

Associate Professor at the Department of Technical English № 2

National Technical University of Ukraine "Igor Sikorsky Kyiv Polytechnic Institute"

(Kyiv,Ukraine)iryna_stavytska@ukr.net

\section{ANALYSIS OF BACHELOR'S PREPARATION FOR THE UNIFIED ENTRANCE EXAM IN A FOREIGN LANGUAGE IN HIGHER EDUCATIONAL INSTITUTIONS IN THE CONDITIONS OF FULL-TIME AND DISTANCE LEARNING}

The authors of the article focus on the peculiarities of preparing bachelors to take the unified entrance exam in a foreign language in higher education in full-time and distance learning and reveal the advantages and disadvantages of preparing undergraduate students to enter the master's program.

An analysis of the tested platforms, which were used at the National Technical University of Ukraine "Igor Sikorsky Kyiv Polytechnic Institute" last academic year proved their effectiveness in preparing for the unified entrance exam.

The authors made a comparative analysis of typical exercises that were recommended to prepare for the unified entrance exam in English to study lexical units and grammatical structures, which would enable future entrants to develop reading skills and comprehension skills and enable them to understand tasks aimed at testing ability and reproduce complete or partial information or find certain facts.

To confirm the effectiveness and necessity of systematic and purposeful work on comprehensive preparation for the exam, the authors monitored the performance of 4th year students. The monitoring was carried out from the moment they started the preparation and until the last version of the tasks developed by the teachers in order to put into practice the knowledge acquired by students on the use of lexical units and English grammar, as well as mastery of various reading techniques.

The article provides the results of the assessment of students' performance of tasks, presents statistics of average indicators of correct answers. Based on the results, conclusions are made on the feasibility and effectiveness of using the recommended manuals in preparing students for the unified entrance exam in a foreign language and recommendations are given on the format of exercises that can be offered to students for face-to-face and distance learning.

Despite some difficulties in the transition from the classroom to distance learning, practitioners, methodologists and scientists are constantly looking for new methods of educational tasks, demonstrate certain methodological developments that can successfully implement the training of future professionals in both full-time and distance learning.

Key words: unified entrance exam, exam strategies, full-time distance learning, typical exercises, lexical minimum, grammatical structures.

Постановка проблеми. Знання іноземної мови є важливим показником професійної компетентності майбутнього фахівця, і тому нині роботодавці визначають знання іноземної мови як один із найважливіших складників сучасної успішної людини. Проведення ділових переговорів 3 іноземними партнерами, інтернет-комунікація, ознайомлення із новітніми світовими розробками потребують знання хоча б однієї іноземної мови. Дослідження засвідчують, що студенти немовних спеціальностей більшість часу витрачають пере- важно на вивчення фахових дисциплін, вивчаючи іноземну мову інколи досить формально. Запровадження єдиного вступного іспиту визначило вивчення іноземної мови в освітніх закладах одним із пріоритетних напрямів.

Єдиний вступний іспит було започатковано у 2017 році як експеримент зі спеціальності «Право». Тоді вступники складали іспити у два етапи: тестування із загальних навчальних правничих компетентностей, тестування із юридичних дисциплін та тестування з іноземної мови. 
Перший рік був експериментальним, і тестування відбулося лише в 5 містах, але результати засвідчили досить високу якість підготовки майбутніх юристів та правознавців. У 2018 році перелік спеціальностей було розширено. До переліку увійшли «Гуманітарні науки», «Соціальні та поведінкові науки», «Журналістика», «Право», «Сфера обслуговування», «Міжнародні відносини».

Також у 2017 році експериментально було запроваджено зарахування сертифікатів замість вступного випробування в університеті або ЄBI. Серед сертифікатів, що приймали на перезарахування з англійської мови: IELTS, TOEFL, Cambridge English Language Assessment; 3 французької мови - DELF, DALF, з німецької мови - TestDaf. Наприклад, у 2017 році 81 вступник подали сертифікати 3 іноземної мови до КПІ ім. Ігоря Сікорського: 3 англійської мови 63 сертифікати, 3 німецької мови 13 сертифікатів, з французької мови 5 сертифікатів.

Хоча навіть зараз абітуріснти, що вступають на навчання для здобуття ступеня доктора філософії, можуть підтвердити свій рівень володіння іноземною мовою відповідним сертифікатом і не складати іноземну мову.

Положення про вступ у 2021 році засвідчує, що вступники всіх спеціальностей України складатимуть іспит у формі єдиного вступного іспиту. Дата проведення основної сесії - 30 червня, дату проведення додаткової сесії буде встановлено пізніше. Вступники на основі диплома ступеня магістра або освітньо-кваліфікаційного рівня «спеціаліст» можуть на вибір обрати вступ у формі СВI або складання вступного іспиту з іноземної мови в університеті.

Єдиний вступний іспит здатен забезпечити прозорість тестування, характеризується високою якістю розроблених тестів, що робить його гідною альтернативою іншим міжнародним тестам, але на цей час лише в межах нашої країни.

Після початку впровадження практики складання єдиного вступного іспиту під час вступу до магістратури ставлення студентів до вивчення дисциплін «Іноземна мова» та «Іноземна мова професійного спрямування» суттєво змінилось. Студенти почали відповідальніше ставитись до процесу підготовки для проходження тесту i критично оцінювати свій рівень знань, який має відповідати вимогам, що висуваються до абітурієнтів. Поступово відбувається переоцінка значимості іноземної мови в житті молодої людини, а особливо майбутнього спеціаліста. Ці фактори вимагають пошуку нових методів та прийомів навчання, а також способів організації навчального процесу, які можуть забезпечити високий рівень підготовки студентів та отримання ними фундаментальних знань із спеціальності, а знання іноземної мови мають тільки допомогти їм у здійсненні їхньої професійної діяльності.

Аналіз досліджень. Досліджуючи питання підготовки студентів до складання іспиту на рівень володіння мовою, необхідно чітко окреслити та розуміти всі фактори, що можуть впливати на цей процес, та складники успіху, що матимуть вирішальне значення під час формування активного усвідомлення студентами широкого кола свого потенціалу, прагнення до саморозвитку та самовдосконалення.

Дуже багато відомих вчених-лінгвістів, методистів-практиків присвятили свої праці вивченню різнобічних сторін методики навчання іноземної мови, висвітленню проблем опанування студентами мови з метою активного її застосування у професійній сфері, а також для подальшого навчання.

Авторами статті проаналізовані дослідження, що присвячувались вивченню проблем тестування. Це питання висвітлено в наукових роботах I. С. Булах, О. П. Петращук, О. О. Леонтьєв, В. С. Аванесова, В. О. Коккота, А. Н. Майорова, R. Millrood, L. Bachman, J. Alderson та багатьох інших наукових діячів. Вони визначають тестову систему, як ефективний метод контролю процесу навчання, дають характеристику різним видам тестів та описують їхні функції (Аванесов, 2005: 1, Коккота, 1989: 6, Леонтьев, 2002: 7, Майоров, 2002: 8, Петращук, 1999: 10, Alderson, 1995: 14, Bachman, 1990: 15, Maslow, 1954: 16). Дослідники тестової методики М. С. Берейгіна та О. М. Смєловська в своїх працях щодо особливостей роботи з іншомовними текстами довели, що тести $є$ не лише ефективним інструментом контролю, але й адаптації (Смєловська, 2003: 11).

Суб'єктом мовного тестування завжди є студент. Саме його якості, що визначатимуть поведінку в умовах тесту, будуть впливати на результати успішності проходження іспиту. Одним із таких факторів є рівень мотивації. Пізнавальна потреба визначається як один з важливих мотивів навчання сучасних студентів. Важливість мотиваційного складника в освітньому процесі та питання внутрішньої мотивації описуються в наукових працях Д. А. Леонтьева, Л. І. Божович, Н. В. Бордовської, В. Г. Асеевої, Г. А. Мухіної, О. Б. Вершинської, C. С. Занюк, A. Maslow (Божович, 1995: 2, Bepшинська, 2009: 4, Занюк, 2002: 5, Маркова, 1990: 9, Смєловська, 2003: 11, Bachman, 1990: 15). 
Досліджуючи питання мотивації навчальної діяльності А. К. Маркова стверджує, що «мотивація навчання складається з ряду тих спонукальних факторів, що постійно змінюються і вступають в нові зв'язки один з одним».

Мотивація визначає прагнення студентів вчитись та опановувати нові знання, включатись в різні види діяльності.

Мета статті - провести аналіз підготовки студентів до складання єдиного вступного іспиту 3 англійської мови до вступу в магістратуру під час очного та в умовах дистанційного режиму навчання. Визначити переваги та недоліки використання різних ресурсів: інтернет-платформ, підручників, дистанційних курсів, вправ, типових завдань, які були апробовані викладачами та студентами нашого університету; їх застосування та доречність використання; розглянути отримані під час моніторингу показники успішності студентів до і після систематичної роботи над виконанням завдань.

Виклад основного матеріалу. Враховуючи досвід минулого навчального року, коли вся робота 3 підготовки студентів велась дистанційно, ми проведемо загальну характеристику підготовки студентів четвертих курсів до тесту EBI 3 англійської мови у 2020 році. Зміст тестів визначено «Програмою єдиного вступного іспиту 3 іноземних мов для вступу на навчання для здобуття ступеня магістра на основі здобутого ступеня вищої освіти (освітньо-кваліфікаційного рівня спеціаліста)», затвердженою наказом Міністерства освіти і науки України від 28 березня 2019 року № 411 «Про затвердження Програми вступного випробування».

Підготовка до складання єдиного вступного іспиту з англійської мови для здобуття ступеня магістра зі студентами бакалаврату КПІ ім. Ігоря Сікорського базувалась на інструкціях щодо змісту тесту, що визначено Програмою єдиного вступного іспиту з іноземних мов. Першою важливою задачею для викладачів іноземної мови перед початком цілеспрямованої та поглибленої підготовки студентів до іспиту було ознайомлення студентів з типовими варіантами завдань. Студенти повинні правильно усвідомлювати та мати чітку інструкцію для розуміння завдання, тоді у них з'являється впевненість, що вони здатні успішно впоратись 3 ним.

Професором, деканом факультету лінгвістики Національного технічного університету України «Київського політехнічного інституту імені Ігоря Сікорського» Н. С. Саєнко та кандидатом педагогічних наук, доцентом КАМТС №2 Національного технічного університету України «Київського політехнічного інституту імені Ігоря Сікорського» О. Ю. Чугай був створений інформаційний ресурс системи дистанційного навчання «Підготовка до CBI $з$ англійської мови» (Чугай, 2014: 13). "EVI test preparation" складається із вступної частини, передмови, системи оцінювання, програми, опису та словника; чотирьох тестів формату СВI (Єдиного Вступного Іспиту) та посилань на використані джерела.

Запропонований інформаційний ресурс системи дистанційного навчання «Підготовка до СВI 3 англійської мови» спрямовано на ефективне сприйняття та засвоєння іншомовного мовленнєвого матеріалу, збагачення словникового запасу студентів та розвиток практичних навичок виконання тестових завдань 3 обмеженням часу, що $\epsilon$ передумовою отримання студентами кращих результатів під час складання $\mathrm{CBI}$.

Тест іспиту складається з трьох видів завдань, які спрямовані на перевірку розуміння прочитаного, а також вміння орієнтуватись в отриманій інформації. Ці навички є дуже важливими i дають можливість оцінити не тільки рівень знань, а також підтверджують значимість розвитку критичного мислення особистості, що дає можливість самостійно оцінювати інформацію, знання та знаходити ефективні рішення.

Дві частини тесту містять завдання на «Читання» та «Використання мови», що є подібним до структури інших міжнародних тестів на виявлення рівня володіння мови. Прикладами таких іспитів можуть бути IELTS, іспити на отримання сертифікату FCE (First Certificate in English).

1 тип завдань. Завдання на встановлення відповідності (Task 1: № 1-5, Task 3: № 11-16).

У завданнях запропоновано дібрати заголовки до текстів / частин текстів 3 наведених варіантів; твердження / ситуації до оголошень / текстів; запитання до відповідей або відповіді до запитань. Завдання вважають виконаним, якщо учасник єдиного вступного іспиту встановив відповідність і позначив варіант відповіді в бланку відповідей В.

2 тип завдань. Завдання з вибором однієї правильної відповіді (Task 2: № 6-10).

Завдання має основу та чотири варіанти відповіді, з яких лише один правильний. Завдання вважають виконаним, якщо учасник єдиного вступного іспиту вибрав і позначив відповідь у бланку відповідей В.

3 тип завдань. Завдання на заповнення пропусків у тексті (Task 4: № 17-22, Task 5: № 23-32, Task 6: № 33-42). У завданнях запропоновано доповнити абзаци / речення в тексті реченнями / 
частинами речень, словосполученнями / словами 3 наведених варіантів. Завдання вважають виконаним, якщо учасник єдиного вступного іспиту вибрав і позначив варіант відповіді в бланку відповідей В.

Нижче наведено приклади таких завдань англійською мовою. Завдання 1 типу.

Task. The following passage has five sections, A-E. Choose the correct heading for a section A-E from the list of numbered headings 1-9.

Task. Choose the correct heading for sections A-D and $\mathrm{F}$ from the list of headings below.

Task. Questions 1-6. The text has four sections, A-D. Which paragraph contains the following information? NB You may use any letter more than once.

Task. You are going to read a text. Seven sentences have been removed from the article. Choose from the sentences A-I the one which fits each gap (1-7). There are two extra sentences, which you do not need to use.

Завдання 2 типу.

Task. Read the text and choose the correct answer for each gap.

Task. Read the text below and decide which option best fits each gap.

Task. Read the following passage and mark the letter A, B, C or D on your answer sheet to indicate the correct word or phrase that best fits each of the numbered blanks from 1 to 15 .

Завдання 3 типу.

Task. Choose the correct option to fill in the gap in the text.

Task. Read the text and choose the most appropriate answer from the given below to fill in the gaps in the sentences.

На практичних заняттях велика увага приділялась вивченню лексичних одиниць, граматичних структур, які б дали можливість майбутнім абітурієнтам проявити сформовані вміння читати текст та розуміти зміст прочитаного, вільно орієнтуватися у завданнях, спрямованих на перевірку здатності відтворити повну, часткову інформацію, чи знайти певні факти з прочитаного.

Кожне практичне заняття зі студентами в ході підготовки до складання іспиту було поділено на дві частини, які органічно поєднували підготовку до професійного спілкування у майбутній професії і підготовку до складання вступного випробування (СBI).

Такий спосіб організації навчального процесу на заняттях дав змогу у стислий термін повторити матеріал, який студенти опановували протягом попередніх років навчання і виявити та надолужити прогалини. Слід відмітити, що студенти охоче виконували вправи, що пропонувались викладачами, оскільки вони є дійсно вмотивовані і мають бажання вивчати та застосовувати англійську мову в своєму професійному житті.

Особливої уваги заслуговує огляд підручників, які радять використовувати для підготовки студентів до складання іспиту. Відразу хочеться зауважити, що їх $є$ багате різноманіття і серед них найбільшою популярністю у наших викладачів користуються такі:

1) FCE Practice Tests Plus, авторів Nick Kenny, Lucrecia Luque-Mortimer. Цей підручник містить різноманітні практичні завдання, що передбачають різнобічну підготовку до іспитів з англійської мови рівня В1, В2. Завдяки вдало підібраним вправам студенти можуть бути успішно підготовленими до складання іспиту. Дуже цікавими та корисними є розділи підручника Teaching not just testing, оскільки містять детальні поради щодо уникнення помилок і на чому слід зосередитись, щоб максимально правильно та ефективно виконувати завдання різного типу.

2) Use of English B2 for all exams, автора E. Moutsou, видавництва MM Publications. Цей посібник має ряд переваг, які підтверджені практикою, оскільки забезпечує систематичну підготовку студентів до іспиту, пропонуючи в кожному розділі виконувати вправи для відпрацювання граматичного матеріалу та оперування новими лексичними одиницями. Підручник дуже насичений матеріалом, а продуктивна і правильно організована робота над ним може гарантувати високий рівень підготовки до складання іспиту.

3) Підручник серії Practice Tests Plus 2, авторів Nick Kenny Lucrecia Luque - Mortimer, видавництва Pearson пропонує готуватись до іспиту, виконуючи тести. Це дуже корисно, оскільки студенти виконують практичні завдання, які є типовими для іспиту, і таким чином можуть одразу оцінити свій рівень підготовки, та виділяють той матеріал, над яким ще треба працювати: це можуть бути розділи з читання або вживання мови, розділи, що спрямовані на трансформацію речень $\mathrm{i}$ перевіряють знання граматики. Підручник також містить аудіо матеріали для перевірки навичок аудіювання, тобто сприйняття мови на слух, що $є$ однією із найважливіших навичок мовлення.

Також можна порадити для підготовки до іспиту та використання на заняттях такі підручники, як Get 200! (Авторів Marta Rodsinska, Lynda Edwards, Malcolm Mann, Steven Taylore-Knowles, видавництво Macmillan, B1-B2 (Book 1 and Book 2); Oxford Exam Excellence, видавництво Oxford, Intermediate to Upper intermediate; Upstream Upper Levels, автор:Virginia Evans Jenny Dooley, видавни- 
цтво Express Publishing (B2 to C2). Всі ці підручники дуже активно використовуються викладачами на заняттях в аудиторіях, а також для самостійного виконання завдань студентами. Самостійна робота студентів з підручником має велике значення, тому що здатна забезпечити безперервну роботу над опануванням мови.

3 накопиченого досвіду викладачів нашого університету щодо вивчення граматичного матеріалу можна дати кілька порад: граматика повинна вивчатись окремим блоком, і її вивчення повинно спиратись лише на виконання практичних вправ. Для контролю та перевірки рівня засвоєння граматичного матеріалу необхідно впровадження тестової системи, що стає доступною за допомогою такого ресурсу, як Classtime та Google forms, які викладач може використовувати, як під час очної, так і під час дистанційної форми навчання.

Щодо підручників для опанування граматикою, то можна порадити Mission 1 або 2; Destination B2, Автора Malcom Mann, видавництва Macmillan; Enterprise Grammar 4; Grammar and Vocabulary for First Certificate, автор: Prodromou, Luke. B2.

Зараз ринок книжок на Україні насичений дуже цікавою та різноманітною навчальною літературою, тому саме викладач, який повною мірою володіє інформацією про рівень знань своїх студентів, повинен правильно орієнтуватись у пропозиціях різних видавництв та підібрати посібник, який буде відповідати його критеріям та вимогам до підручника.

Проте проблема обмеження часу та кількості навчальних годин, відведених на підготовку абітурієнтів до складання іспиту, диктує свої правила.
Робота викладача в процесі підготовки студентів до складання іспиту повинна базуватись на певних принципах та критеріях:

- іспит чітко окреслює той обсяг лексико-граматичного матеріалу, який повинен бути засвоєний студентами до моменту іспиту;

- іспит дисциплінує викладача і дає йому можливість навчитися більш якісному управлінню часом (time-management skills);

- іспит дозволяе конкретним чином оцінити ступінь засвоєння матеріалу, що пояснюється.

Викладачі іноземної мови повинні шукати шляхи та підходи, як зробити цей процес ефективним та цікавим і в той же час забезпечити інтенсивну підготовку студентів.

3 цією метою авторами статті були розроблені варіанти завдань, які можуть бути використані як на заняттях в аудиторії, а також у вигляді тестів для проходження студентами дистанційно.

Кожен варіант складався із завдань на читання, використання мови та граматичний матеріал, тобто трьох блоків, які були націлені на комплексну підготовку студентів. Кожен блок складався 3 10 питань. Всі завдання були типовими для складання іспиту, тому студенти мали чудову нагоду практикуватись та аналізувати свої помилки.

Нами був проведений моніторинг показників успішності студентів від моменту, як вони почали практикуватись, і до моменту виконання останнього варіанту завдань. Ми оцінювали успішність виконання студентами завдань (кількість правильних відповідей) кожного блоку. На діаграмі ми бачимо середні показники правильних відповідей

Кількість правильних відповідей за блоками завдань

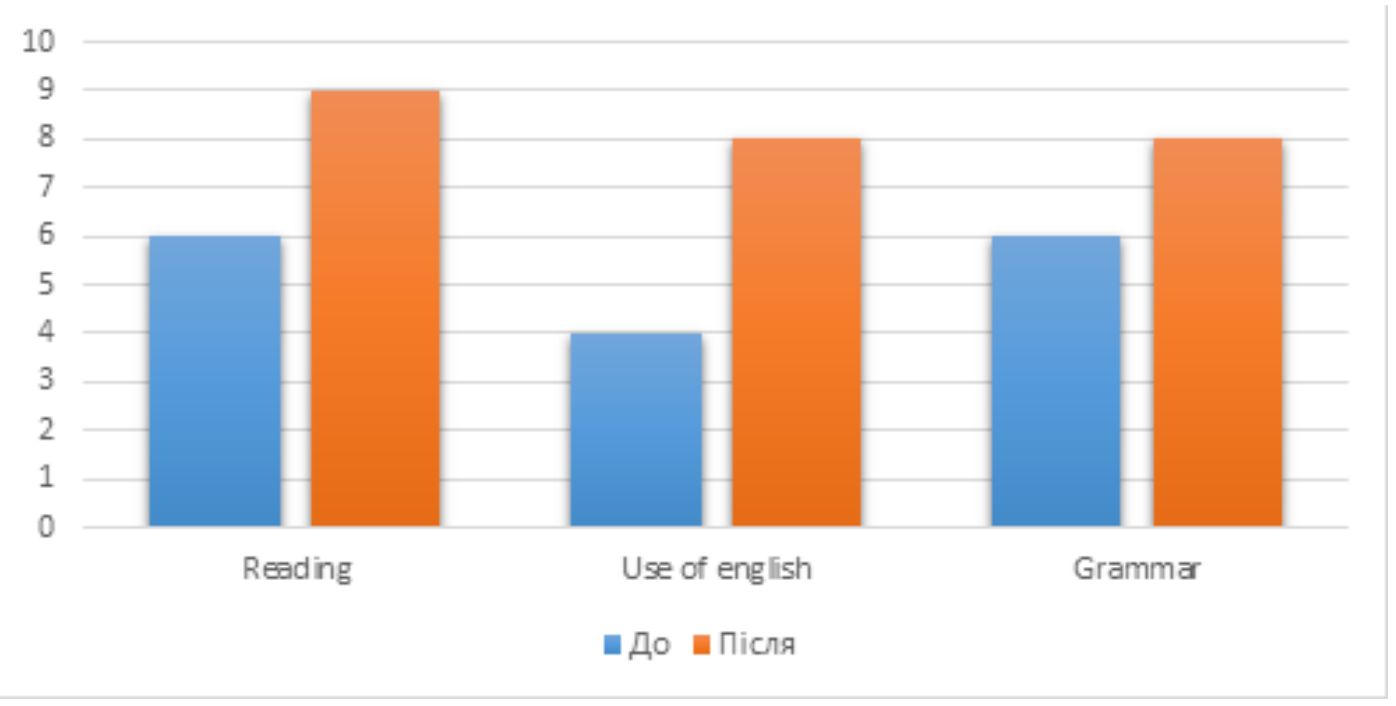

Рис. 1. Середні показники правильних відповідей до і після систематичної роботи над виконанням завдань 
до і після систематичної роботи над виконанням завдань (рис. 1).

Наведені на діаграмі дані підтверджують той факт, що систематична робота та комплексний підхід дали позитивну динаміку та покращили рівень знань студентів. Звісно, це не може гарантувати, що вони всі дуже успішно складуть іспит, тому що це залежить від різних чинників, але базову підготовку вони отримали та відчуття впевненості на іспиті обов'язково матимуть.

Але вирішальним фактором, звісно, була та залишається мотивація студентів у необхідності подолати наступний етап свого професійного становлення.

Успішно складений іспит уможливлює отримання другого рівня вищої освіти. Ступінь магістра гарантує подальший професійний ріст та можливість долучитись до наукових проєктів не тільки в нашій країні, а і закордоном. Професійний інтерес повинен бути рушійним стимулом до навчання в університеті протягом всього періоду, а потреба у вищій освіті є вимогою суспільства на сучасному етапі його розвитку.

Мотивація $є$ головною рушійною силою будьякої діяльності людини і професійна діяльність не $є$ винятком. Вона $є$ одним із провідних факторів успішного навчання молодої людини, а отже, iї професійного становлення. Розвиток позитив- ної навчальної мотивації у студентів $є$ однією 3 умов розвитку особистості та ефективної професійної підготовки (Бондар, 2017: 3). Будь-яка педагогічна взаємодія в системі «викладач - студент» стає ефективною тільки 3 урахуванням особливостей мотивації.

Висновки. Після проведення аналізу роботи, що була спрямована на підготовку студентів до складання іспиту, ми можемо говорити про те, що застосування різних методичних прийомів, матеріалів може забезпечити якісну підготовку студентів до складання іспитів формату СВI та інших стандартизованих тестів 3 англійської мови, що перевіряють рівень володіння мовою. Проте це стає можливим лише за умови реалізації такої підготовки в різних напрямах та іiі органічного узгодження 3 вимогами та чинними робочими програмами дисциплін «Іноземна мова» та «Іноземна мова професійного спрямування». Комплексний підхід до здобуття професійної освіти передбачає вирішення не тільки освітніх, але і розвиваючих та виховних цілей. Послідовність роботи по досягненню цих цілей гарантує підготовку висококваліфікованого фахівця, здатного швидко реагувати та пристосовуватись до нових вимог суспільства, бути мобільним щодо отримання освіти в будь-якому університеті світу та планувати свою професійну кар'єру.

\section{СПИСОК ВИКОРИСТАНИХ ДЖЕРЕЛ:}

1. Аванесов В. Форма тестовых заданий. Учебное пособие для учителей школ, лицеев, преподавателей вузов и колледжей. Москва : Центр тестирования, 2005. 156 с.

2. Божович Л. И. Избранные психологические труды: Проблемы формирования личности. Москва : Международная педагогическая академия, 1995. 209 с.

3. Бондар Л. В. Особливості мотивації навчальної діяльності студентів - майбутніх практичних психологів. URL: http://jrnl.nau.edu.ua/index.php/VisnikPP/article/view/12459 (дата звернення: 20.11.2020).

4. Вершинська О. Б. Проблеми формування навчальної мотивації студентів BH3. URL: http://tme.umo.edu.ua/ dodatok.htm (дата звернення: 15.11.2020).

5. Занюк С. С. Психологія мотивації: навч. посіб. Київ : Либідь, 2002. 304 с.

6. Коккота В. А. Лингводидактическое тестирование : науч.-теорет. пособие. Москва : Высш. шк., 1989. 127 с.

7. Леонтьев Д. А. Современная психология мотивации. Москва : Смысл, 2002. 343 с.

8. Майоров А.Н. Теория и практика создания тестов для системы образования. Москва:Интеллект-Центр, 2002.56 с.

9. Маркова А. К. Формирование мотивации учения: Кн. для учителя. Москва : Просвещения, 1990. 192 с.

10. Петращук О. П. Тестовий контроль у навчанні іноземної мови в середній загальноосвітній школі : монографія. Київ : Вид.центр КДЛУ, 1999. 261 с.

11. Смєловська О. М. Різнорівневі тестові завдання з англійської мови: методичний матеріал. 2003. С. $32-37$.

12. Про затвердження умов прийому на навчання для здобуття вищої освіти в 2021 році. URL: https://mon.gov. ua/ua/npa/pro-zatverdzhennya-umov-prijomu-na-navchannya-dlya-zdobuttya-vishoyi-osviti-v-2021-roci (дата звернення: 15.11.2020)

13. Чугай О. Ю. Програми дистанційного навчання педагогів в університетах США. Педагогічна компаративістика: якісний вимір освіти зарубіжжя та український контекст: Всеукраїнський науково-практичний семінар, м. Київ, 5 червня 2014 р. Київ : Педагогічна думка, 2014. С. 168-169.

14. Alderson J. C. Language Test Construction and Evaluation / J.C.Alderson, C. Clapham, D. Wall. Cambridge : CambridgeUniversityPress, 1995. 324 p.

15. Bachman L. Fundamental consideration in language testing. Oxford: Oxford University Press, 1990. 268 p.

16. Maslow A. H. (1954). Motivation and personality. Harpers. URL: https://psycnet.apa.org/record/1955-02233-000 (дата звернення: 15.11.2020).

17. Millrood R.(2002). Theory of Language Teaching. Volume 1.Applied Linguistics. Tambov: University of Tambov Press. 


\section{REFERENCES:}

1. Avanesov V. Forma testovyh zadanij [Form of test items]. Textbook for teachers of schools, lyceums, teachers of universities and colleges. Moscow : Centr testirovaniya, 2005. 156 p. [in Russian].

2. Bozhovich L. I. Izbrannye psihologicheskie trudy: Problemy formirovaniya lichnosti [Selected psychological works: Problems of personality formation]. Moscow : Mezhdunarodnaya pedagogicheskaya akademiya, 1995. 209 p. [in Russian].

3. Bondar L. V. Osoblivosti motivaciyi navchalnoyi diyalnosti studentiv - majbutnih praktichnih psihologiv [Features of motivation of educational activity of students - future practical psychologists] URL: http://jrnl.nau.edu.ua/index.php/ VisnikPP/article/view/12459 [in Ukrainian].

4. Vershinska O. B. Problemi formuvannya navchalnoyi motivaciyi studentiv VNZ [Problems of the formation of educational motivation of university students] [in Ukrainian].

5. Zanyuk S. S. Psihologiya motivaciyi [Psychology of motivation]: navch. posib. Kyiv : Libid, 2002. 304 p. [in Ukrainian].

6. Kokkota V. A. Lingvodidakgicheskoe testirovanie [Linguodidactic testing]: Nauch. -teoret. posobie. Moscow : Vyssh. shk., 1989. 127 p. [in Russian].

7. Leontev D.A. Sovremennaya psihologiya motivacii [Modern psychology of motivation]. Moscow : Smysl, 2002. 343 p. [in Russian].

8. Majorov A. N. Teoriya i praktika sozdaniya testov dlya sistemy obrazovaniya [Theory and practice of creating tests for the education system]. Moscow: Intellekt-Centr, 2002. 56 p. [in Russian].

9. Markova A. K. Formirovanie motivacii ucheniya [Formation of motivation for learning]: Kn. dlya uchitelya. Moscow : Prosvesheniya, 1990. 192 p. [in Russian].

10. Petrashuk O.P. Testovij kontrol u navchanni inozemnoyi movi v serednij zagalnoosvitnij shkoli [Test control of teaching a foreign language at the secondary school]: Monografiya. Kyiv : Vid.centr KDLU, 1999. 261 p. [in Ukrainian].

11. Smyelovska O.M. Riznorivnevi testovi zavdannya $\mathrm{z}$ anglijskoyi movi [Multi-level English language tests]: metodichnij material. 2003. pp. 32-37 [in Ukrainian].

12. Pro zatverdzhennya umov prijomu na navchannya dlya zdobuttya vishoyi osviti v 2021 roci [Approval of admission conditions for higher education in 2021] URL: https:/mon.gov.ua/ua/npa/pro-zatverdzhennya-umov-prijomu-na-navchannya-dlya-zdobuttya-vishoyi-osviti-v-2021-roci [in Ukrainian].

13. Chugaj O. Yu. Programi distancijnogo navchannya pedagogiv v universitetah SShA. Pedagogichna komparativistika: yakisnij vimir osviti zarubizhzhya ta ukrayinskij kontekst: Vseukrayinskij naukovo-praktichnij seminar, m. Kiyiv, 5 chervnya 2014 r. Kyiv : Pedagogichna dumka, 2014. S. 168-169. [in Ukrainian].

14. Alderson J. C. Language Test Construction and Evaluation / J.C. Alderson, C. Clapham, D. Wall. Cambridge: Cambridge University Press, 1995. 324 p. [in English]. lish].

15. Bachman L. Fundamental consideration in language testing. Oxford: Oxford University Press, 1990. 268 p. [in Eng-

16. Maslow A. H. (1954). Motivation and personality. Harpers. URL: https://psycnet.apa.org/record/1955-02233-000 [in English].

17. Millrood R. (2002). Theory of Language Teaching. Volume 1. Applied Linguistics. Tambov : University of Tambov Press. [in English]. 